\title{
Management of the Water Slide Brought and Saline Flow in Irrigated Onion (Allium cepa L.) Cultivation in the Senegal River Delta
}

\author{
Eric Kaly ${ }^{1}$, Oumar Sarr ${ }^{1}$, Raymond Malou ${ }^{2}$, Sékouna Diatta1, Daouda Ngom¹, Aliou Guisse ${ }^{1}$ \\ ${ }^{1}$ Laboratory of Plant Ecology and Eco-Hydrology, Department of Plant Biology, Cheikh Anta Diop University, Fann, Dakar, Senegal \\ ${ }^{2}$ Hydrogeology Laboratory, Department of Geology, Cheikh Anta Diop University, Fann, Dakar, Senegal \\ Email: ${ }^{\star}$ kalyeric@gmail.com
}

How to cite this paper: Kaly, E., Sarr, O., Malou, R., Diatta, S., Ngom, D. and Guisse, A. (2021) Management of the Water Slide Brought and Saline Flow in Irrigated Onion (Allium cepa L.) Cultivation in the Senegal River Delta. Agricultural Sciences, 12, 1255-1268.

https://doi.org/10.4236/as.2021.1211080

Received: September 14, 2021

Accepted: November 12, 2021

Published: November 15, 2021

Copyright $\odot 2021$ by author(s) and Scientific Research Publishing Inc. This work is licensed under the Creative Commons Attribution International License (CC BY 4.0).

http://creativecommons.org/licenses/by/4.0/

(c) (i) Open Access

\begin{abstract}
The find for the optimal slide of water to bring to the plot during the irrigated onion crop was important in order to limit the recharge of the water table close to the soil surface. The quantities of water supplied during onion irrigation were estimated from measurements made with a metal crest to the plot positioned at the tertiary canal. The flow rates at the tertiary canal directly irrigating the plot were recorded during irrigation. From this flow rate, the quantity of water supplied to each plot was determined. From then, the performance of the irrigated system in onion cultivation should pass on the management of this water slide at the level of the hydroagricultural facilities. The integrated soil water mass, salinity and water table dynamics monitoring system was used to assess the water requirements of onion following the irrigation. The daily water requirement of onion in the holland soil of the delta was estimated to average $0.45 \mathrm{~g} / \mathrm{m}^{3}$. These requirements were varied according to the development stage of the crop. The water level between the ridges was between 6 and $9 \mathrm{~mm}$ during irrigation. This was not permanent, it infiltrated between 12 and 18 hours. This type to the stingray irrigation did not favour the arrival of the water table on the surface. The only fluctuations in the water table were observed during the bulb maturation phase. During this phase, the soil water masses were important. The electrical conductivity recorded varied during the campaign. At the beginning of irrigation, it was 3.62 $\mathrm{mS} / \mathrm{cm}$ on a $30 \mathrm{~cm}$ profile, it decreased towards the end of the irrigations to reach $2.06 \mathrm{mS} / \mathrm{cm}$. The quantities of salt recorded on a $30 \mathrm{~cm}$ profile varied from one month to the next; they were $0.468 \mathrm{t} / \mathrm{ha}$ at the beginning of irrigation (January) and $0.275 \mathrm{t} / \mathrm{ha}$ at the end of the campaign (April). From these results we can say that land degradation in the Senegal river delta would be linked to the arrival of salty groundwater on the surface.
\end{abstract}




\section{Keywords}

Slide of Water, Water Mass, Stingray Irrigation, Billon, Salinity, Onion

\section{Introduction}

In the delta area, market gardening is developing with a large share devoted to the cultivation of onions (Allium cepa L.), which is the most produced and consumed vegetable in Senegal [1]. At the economic plan, this irrigated crop occupied the first place in terms of income ahead of rice cultivation, especially since onion was arriving the market when demand was high and prices were high [2].

In the delta, onion cultivation is now closely linked to the main crop, rice growing, especially as it occupies the same plots, shares the same irrigation networks and follows it in the calendar [3]. In contrast to rice cultivation, irrigation in onion cultivation mobilises less important volumes of water [4]. However, depending on the type of irrigation, a number of problems occur in onion production, preventing the plant from developing its full potential [5]. This situation wears prejudice to the commercial output of the culture and the quality of products. The irrigation of the plants during culture seems to have a determining role [6]. The irrigation of the plants during culture seems to have a determining role. In fact, if it is well controlled, furrow irrigation should be preferred to basin irrigation, especially in heavy soils [7]. In the delta area, the frequency and irrigation rhythm in market gardening (irrigated onion cultivation) are left to the discretion of the producers, although there are tools to help with decision plug making exist. The latter is increasingly used in agriculture for decision-making. This is how the main objective of this study is to make a daily follow-up of the water of the irrigations of the plots thanks to the sampling of the soil moisture rates in order to determine the quantities of water necessary to the plant during the cycle and to define the frequency to arrive at a better management of the plots in irrigated culture of onion.

\section{Materials and Methods}

\subsection{Presentation of the N'Diaye Irrigated Area}

The village of N'diaye, which hosts the irrigated perimeter, is located $35 \mathrm{~km}$ from the city of Saint-Louis in a transition area between the oceanic influenced climate and the semi-desert climate [8]. At the geomorphologically plan, the agricultural perimeter is located in a settling bowl, a topographical depression with clay soil that limits, a priori, infiltration and therefore favours rice and market gardening [9].

The Ndelle and Ndiaye perimeters were created in 1978, forming a single development known as the Ndelle-Ndiaye bowl [10]. With the restructuring that took place in 1989 during the new agricultural policy and the disengagement of 
the SAED, they were separated and transformed into a large non-transferred development [11]. Thus, this perimeter was managed by a Hydraulic Union to which SAED would have entrusted the responsibility of exploitation. In 2008, within the framework of the Lampsar left bank project, the facilities were rehabilitated and the exploitable area of the N'diaye perimeter is evaluated at 274 ha [9].

\subsection{Crop Data}

The most commonly grown onion variety in the Senegal river delta was Galmi [12]. After 4 - 5 weeks in the nursery, the young plants were transplanted in early January and harvested about 100 days later in April [12]. At difference to rice cultivation, irrigated onion cultivation was practised on plots ploughed in ridges (Figure 1). Before transplanting, pre-irrigation was carried out the day before. The transplanted plants were between $10 \mathrm{~cm}$ and $12 \mathrm{~cm}$ high. All the plots were irrigated at stingrays. For this study, the hypothesis formulated was that there was no fertility stress existed and that the recommended local doses of nutrient have been applied, i.e. 750 - $1000 \mathrm{~kg} / \mathrm{ha}$ of organic manure, $300 \mathrm{~kg} / \mathrm{ha}$ of NPK 10-10-20 and $100 \mathrm{~kg} / \mathrm{ha}$ of urea [12]. A chemical treatment (osophore or Super large Califlora) of weeds was applied to the plots. However, all plots were regularly weeded.

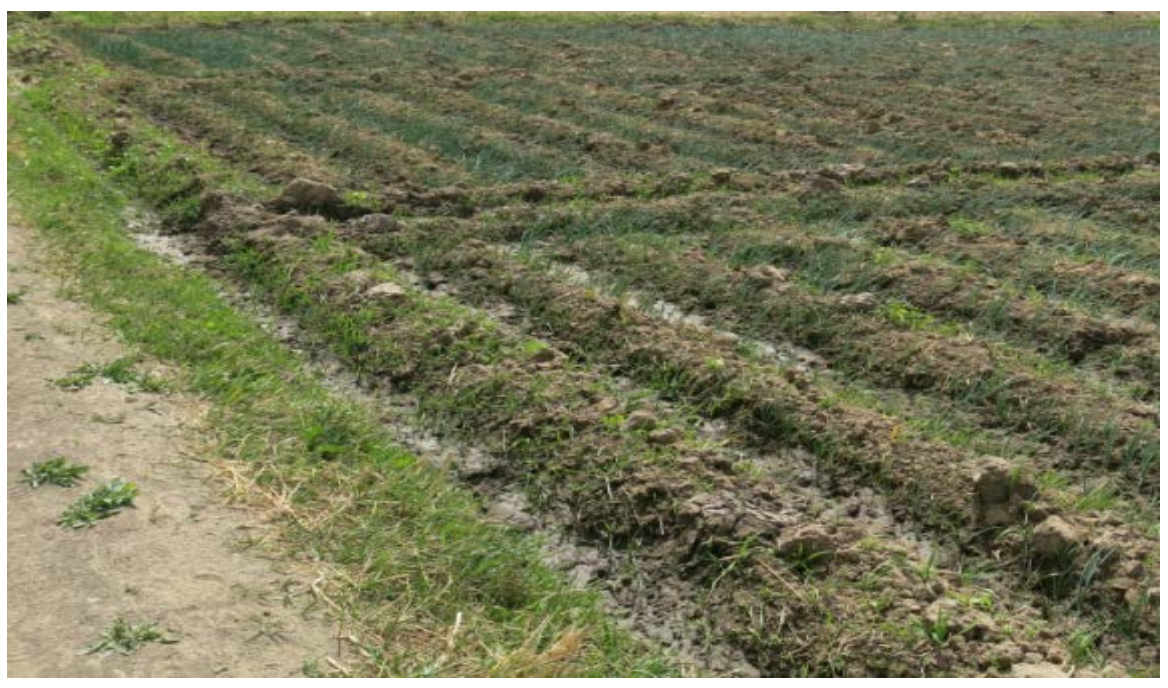

Figure 1. Irrigated onion cultivation by ridging.

\subsection{Assessment of Real Evapotranspiration}

The real evapotranspiration in irrigated onion cultivation in the N'diaye bowl was determined from data collected at the AfricaRice meteorological station in N'diaye. To calculate the real evapotranspiration it is necessary to determine the reference potential evapotranspiration (rPET), which was estimated by the FAO Penman-Monteith method [13]. The real evapotranspiration of the crop was calculated by multiplying the reference potential evapotranspiration of the site with the crop coefficient $(\mathrm{kc})$, the value of which depends on the development stage of the 
crop. The crop coefficients for onions at different stages of development have been defined by Van Leare (2003) [14] in "The Irrigation Memento" (Table 1).

Table 1. Crop coefficients for onion according to development stage.

\begin{tabular}{ccc}
\hline Kc init (4 - 5 leaf stage) & Kc mid (bulb maturation stage) & Kc fin (maturity stage) \\
\hline 0.7 & 1.5 & 0.85 \\
\hline
\end{tabular}

\subsection{Monitoring Water Inputs during Irrigation}

The quantities of water brought to the plot during the irrigated cultivation of onions have been often difficult to estimate in view of to the gravity at stingrays irrigation method used [12]. In the framework of this study, for a good quantification of water inputs, a technique was developed to measure the hydric flow in the tertiary canals irrigating the plots. The Hydric flows in the tertiary canals directly irrigating the plots were recorded during irrigation. The experimental device was a metal crest with a spout facing the plot. The filling time of a container of known volume was timed. After different tests on the experimental plots the average flow rate was obtained. This hydric flow observed at the level of the tertiary channels connecting the secondary channel to the plots depended directly on the water level in the latter (Figure 2). This measurement had allowed to have an idea of the quantities of water brought in, knowing the duration of each irrigation. At each irrigation, the height of the water slide level between two ridges was measured from a graduated scale. This water slide was a function of the proximity of the plot at the conduct principal due to the use of the gravity system during irrigation. This water slide was not permanent, it was lost by infiltration and/or percolation a few hours after irrigation (Figure 3).

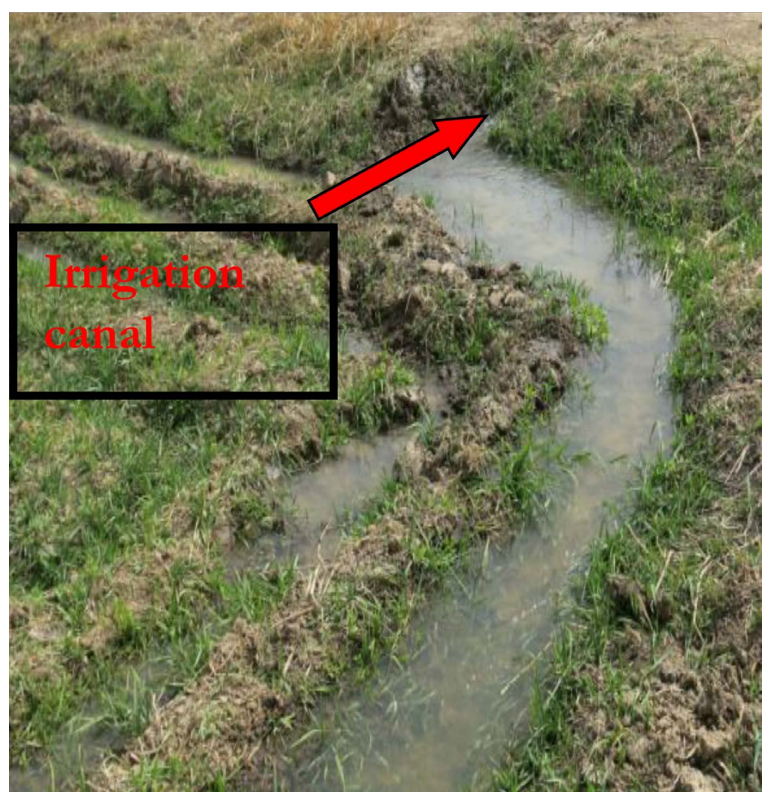

Figure 2. Furrow irrigation system in an onion crop. 


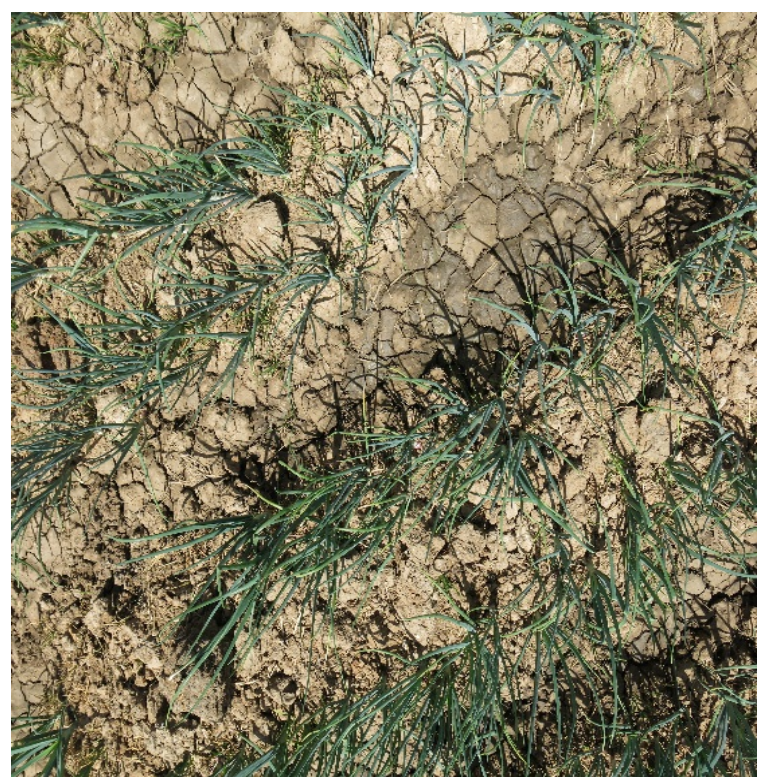

Figure 3. Condition of the plot the day after irrigation.

\subsection{Monitoring of Soil Water Content}

In irrigated cultivation, knowledge of the hydric profiles and electrical conductivity of a slice of soil were fundamental to follow the migration fronts of moisture and solutes during infiltration [15].

The water content of a soil varies between a minimum value (the residual water content, $\theta \mathrm{r}$ ) and a maximum value (the saturation water content, $\theta$ s). The saturation water content is in principle equal to the porosity of the soil, i.e. all the pore space is occupied by the solution. In reality, it is always lower than this porosity value due to air trapping [16]. However, there are several methods to assess the amount of water present in the soil during irrigated onion cultivation or volumetric water content. For this study, the gravimetric method (weighing, drying at proofer and weighing) was used. It consisted of taking soil samples at depths of $15 \mathrm{~cm}$ and $30 \mathrm{~cm}$ level the experimental plots to assess the water content of the soil. Soil cores were augered just after the irrigation water has been infiltrated and on the eve of the next irrigation. They were then preserved in moisture-retaining rings and forwarded to the laboratory where the gravity method was applied. To do this, the soil samples were weighed in a cool place and then past in an proofer at $105^{\circ} \mathrm{C}$ for 48 hours. From the water content profiles obtained, the water stock contained in the soil per unit area was evaluated and then translated into water slide equivalent [16]. Gravimetric water content was measured weekly at $15 \mathrm{~cm}$ and $30 \mathrm{~cm}$ depths. For each measurement three repetitions were made per plot.

\subsection{Monitoring of Groundwater Table Dynamics}

Monitoring of the dynamics of the groundwater table was carried out by a device consisting of a network of piezometers. This device was set up within the 
framework of the "control of irrigation water for sustainable agriculture" project. A line of piezometers (P1, P3, P5 and P7) was drilled along the secondary canal during the project. These piezometers were $6 \mathrm{~m}$ deep and have been screened at the base. Measurements were carried out in three phases: before irrigation, throughout the crop cycle (January-April) and after the onion harvest (May-June) to properly describe the fluctuation of groundwater in relation to inputs. Measurements were made weekly.

\subsection{Monitoring of Electrical Conductivity}

The assessment of electrical conductivity (EC) at plot level during the campaign was carried out by taking soil samples followed by laboratory analysis. These samples were taken manually by auger at depths of $30 \mathrm{~cm}$ as onion bulbs did not exceed this depth at maturity. Once in the laboratory, they were analysed according to the soil/water ratio $=1 / 5[17]$.

\section{Results}

\subsection{Irrigation Schedule}

At irrigated onion cultivation before transplanting the plots has been pre-irrigated. This pre-irrigation had of role to facilitate transplanting activity to mitigate ridges temperatures and to keep the root system in the soil. Fifteen days after transplanting, the first irrigation of plots C (C1-4) and F (F1-F2) was carried out (Table 2) thereafter an irrigation frequency of twelve days interval was applied. During the bulbaison and ripening phases the irrigation intervals were sometimes reduced from twelve to one week depending on the behaviour of the crop (Table 2). After the bulbs had matured and once the leaf senesced was completed, irrigation was stopped, time to lef the bulbs to dry out before harvesting.

Table 2. Irrigation dates (January-March).

\begin{tabular}{|c|c|c|c|c|c|c|c|c|c|c|}
\hline \multirow{2}{*}{ Name } & \multirow{2}{*}{ Variety } & \multirow{2}{*}{ Plot code } & \multirow{2}{*}{$\begin{array}{c}\text { Transplanting } \\
\text { date }\end{array}$} & \multirow{2}{*}{ Pre-irrigation } & \multirow{2}{*}{$\begin{array}{c}1 \\
\text { irrigation }\end{array}$} & \multirow{2}{*}{$\begin{array}{c}2 \\
\text { irrigation }\end{array}$} & \multirow{2}{*}{$\begin{array}{c}3 \\
\text { irrigation }\end{array}$} & \multirow{2}{*}{$\begin{array}{c}4 \\
\text { irrigation }\end{array}$} & \multirow{2}{*}{$\begin{array}{c}5 \\
\text { irrigation }\end{array}$} & \multirow{2}{*}{$\begin{array}{c}6 \\
\text { irrigation }\end{array}$} \\
\hline & & & & & & & & & & \\
\hline \multirow{4}{*}{ Mr DER } & \multirow{4}{*}{$\begin{array}{l}\text { Purple } \\
\text { Galmi }\end{array}$} & $\mathrm{C} 1$ & $05 / 01$ & $04 / 01$ & $20 / 01$ & $01 / 02$ & $13 / 02$ & $01 / 03$ & $07 / 03$ & $21 / 03$ \\
\hline & & $\mathrm{C} 2$ & $06 / 01$ & $05 / 01$ & $20 / 01$ & $01 / 02$ & $13 / 02$ & $01 / 03$ & $07 / 03$ & $21 / 03$ \\
\hline & & $\mathrm{C} 3$ & $07 / 01$ & $06 / 01$ & $20 / 01$ & $01 / 02$ & $13 / 02$ & $01 / 03$ & $07 / 03$ & $21 / 03$ \\
\hline & & $\mathrm{C} 4$ & $08 / 01$ & $07 / 01$ & $20 / 01$ & $01 / 02$ & $13 / 02$ & $01 / 03$ & $07 / 03$ & $21 / 03$ \\
\hline \multirow{2}{*}{ Mr FALL } & Purple & $\mathrm{F} 1$ & $05 / 01$ & $04 / 01$ & $20 / 01$ & $31 / 02$ & $07 / 02$ & $14 / 03$ & $28 / 03$ & $15 / 03$ \\
\hline & Galmi & $\mathrm{F} 2$ & $05 / 01$ & $04 / 01$ & $20 / 01$ & $31 / 02$ & $07 / 02$ & $14 / 03$ & $28 / 03$ & $15 / 03$ \\
\hline
\end{tabular}

\subsection{Soil Water Balance}

Figure 4 allowed the evolution of the soil water reserve over time along the crop cycle. In non-flooded irrigated cultivation (absence permanent of the water slide during the crop cycle), the state of the soil water reserve could be appreciated by 
means of a water balance as the quantity of water consumed by the crop. The water mass in the soil had remained largely above the evapotranspiration of the onion, thus sufficient to cover the water needs (Figure 4). At the end of the crop cycle, evapotranspiration was higher than the soil water mass, allowing dryning the onion bulbs. This water balance, which was the difference between the "water inputs" (irrigation in the case of an irrigated crop) and the "outputs" (water losses through evapotranspiration, drainage, percolation, consumption by the plant), made it possible to estimate the quantities available in the soil that were supposed to be usable by the crop (Figure 4).

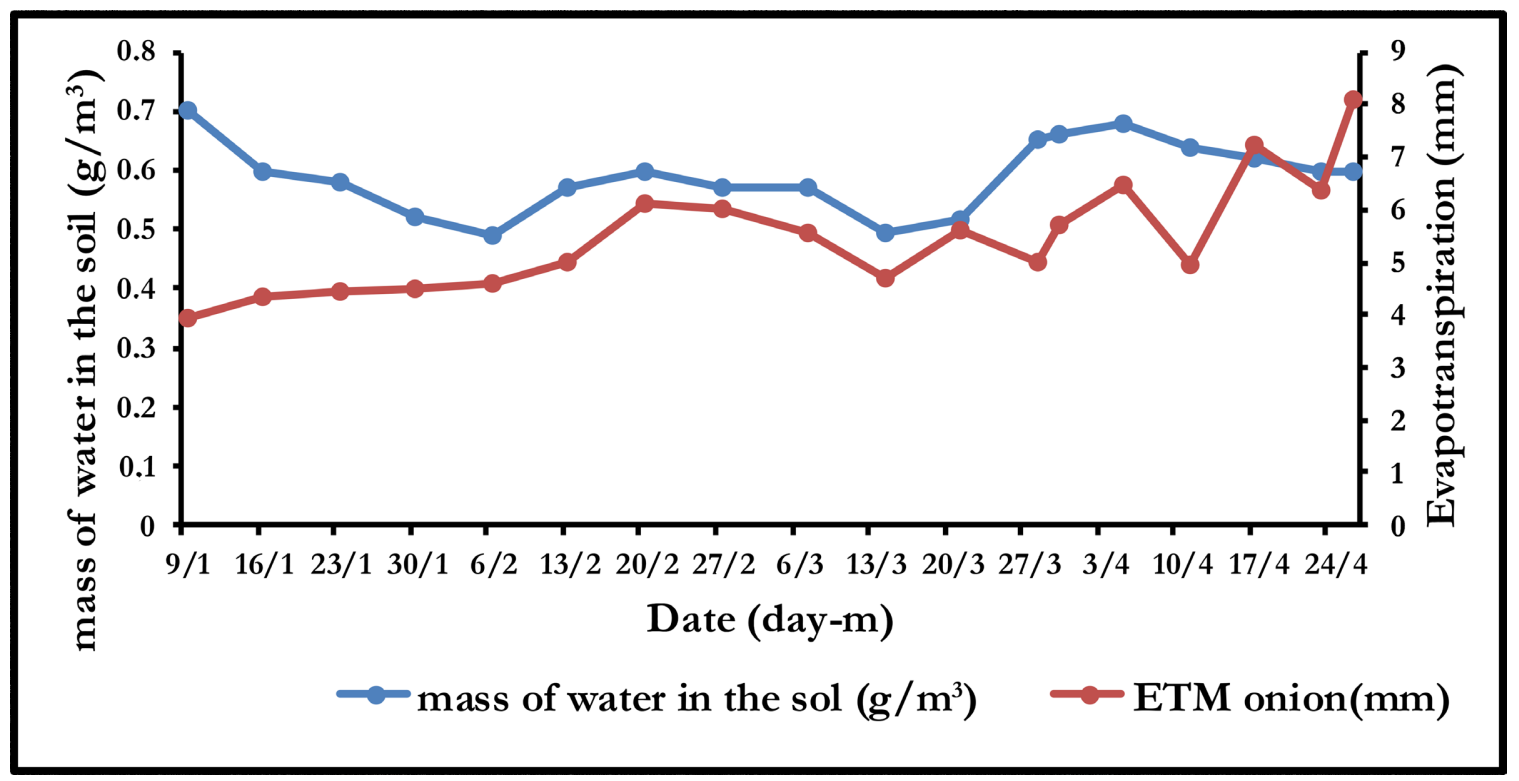

Figure 4. Relationship between water mass in the soil and evapotranspiration losses.

\subsection{Evapotranspiration}

The water content by volumic of the soil in a $30 \mathrm{~cm}$ profile at irrigated onion cultivation in the delta in the counter-hot season averaged $0.625 \mathrm{~g} / \mathrm{m}^{3}$. It was maximum $\left(0.680 \mathrm{~g} / \mathrm{m}^{3}\right)$ at the bulb growth phase (Figure 5). During this phase the onion was very sensitive to water stress. Therefore, in the absence of a permanent water slide on the soil surface due to the irrigation method used (by ridging), the only water losses observed in the plots were crop evapotranspiration. The daily evapotranspiration varied between $4 \mathrm{~mm}$ and $8 \mathrm{~mm}$ with an average of 5.50 $\mathrm{mm}$ /day. This evapotranspiration varied according to the development stage of the crop (Figure 5). In short, despite the water losses through evapotranspiration, the mass of water retained in the soil was sufficient to cover the water needs of the plant (Figure 5).

From the results of the observed water content in the plots, a simulation was made to estimate the water mass that could cover the water needs of the crop (Figure 5). During the whole the season, the observed soil water content exceeded that simulated (Figure 5). 


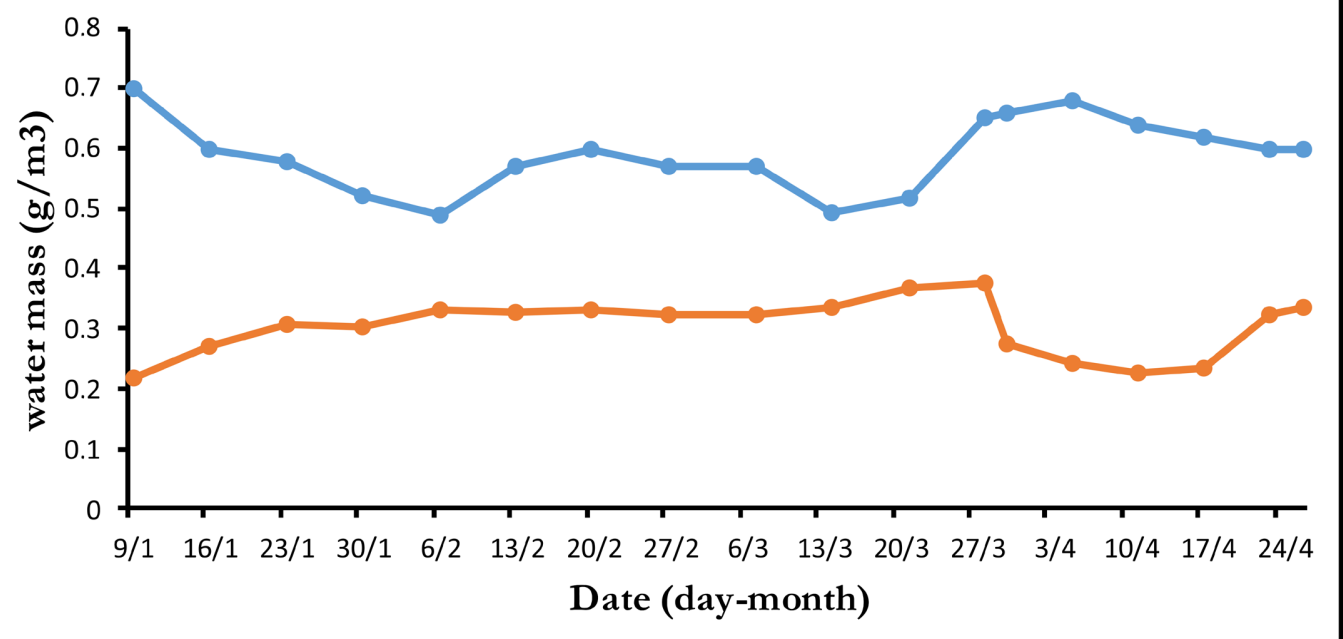

$\longrightarrow$ mass of water in the sol $\left(\mathrm{g} / \mathrm{m}^{3}\right) \multimap$ Simulated water content $\left(\mathrm{g} / \mathrm{m}^{3}\right)$

Figure 5. Observed and simulated soil water content during the campaign.

\subsection{Relationship between Soil Volumic Water Mass and the Dynamics of the Groundwater Table}

In the irrigated area of N'diaye, the monitoring of the dynamics of the water table during irrigated onion cultivation was monitored. Figure 6 highlights the behaviour of the water table as a function of the water mass present in the soil

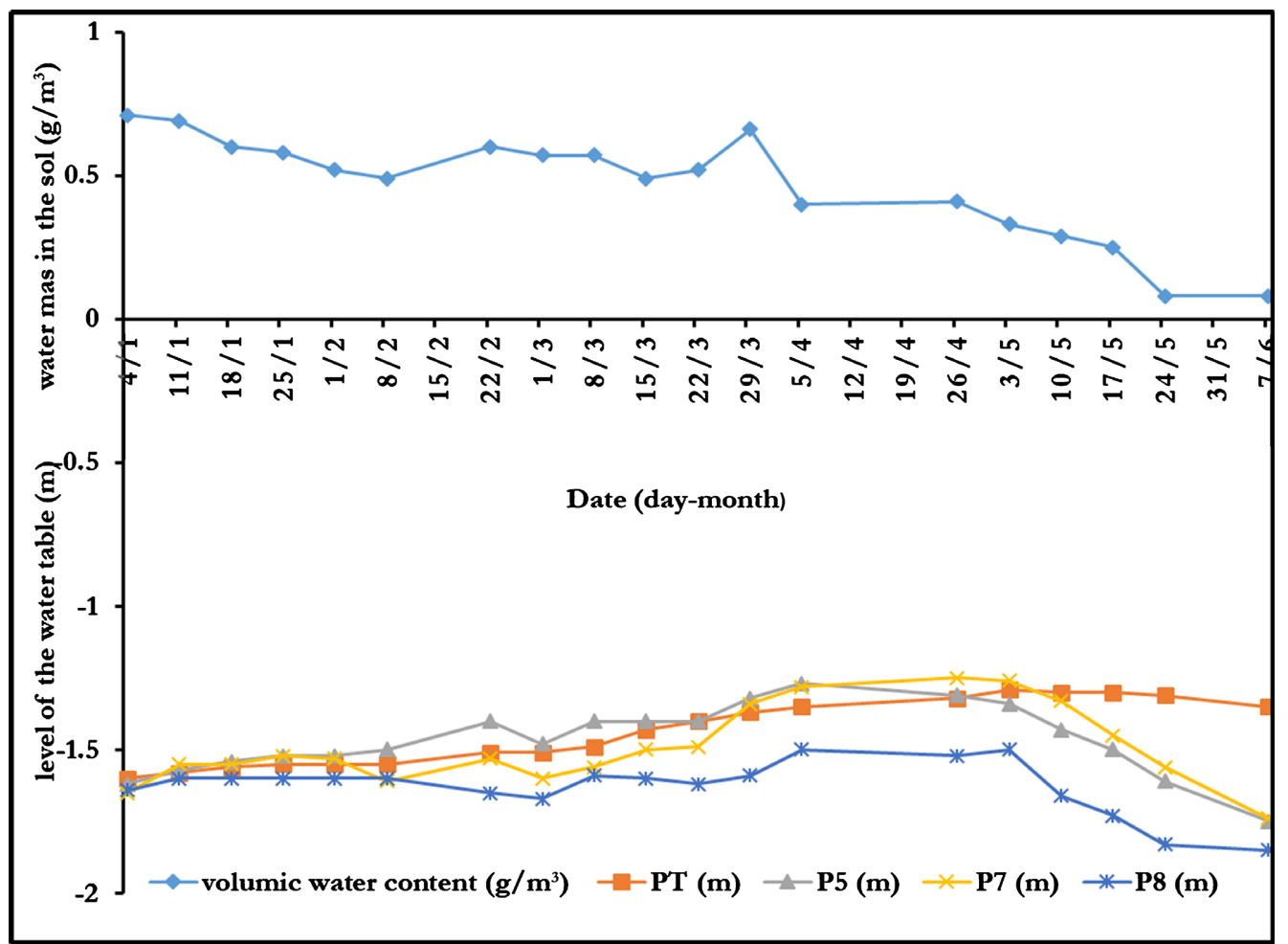

Figure 6. Relationship between water mass volumic and water table dynamics in irrigated onion cultivation. 
during the campaign. During this campaign, with the stingray irrigation system, the percolation and/or infiltration of irrigation water was low and hardly had reached the water table, resulting in less recharge of the water table. On the other hand, during the bulbing and ripening phase, the bulbs were very sensitive to the drop in soil water content, which hinders their development. From then on, producers did not hesitate to bring in large quantities of water, thus causing a slight rise in the groundwater table (Figure 6).

\subsection{Variability of Electrical Conductivity as a Function of the Water Mass in the Soil}

The results obtained with the soil sample analysis method had established a relationship between volumic water content and electrical conductivity (Figure 7). At the beginning of the crop irrigations the electrical conductivity had reached its maximum $(3.62 \mathrm{mS} / \mathrm{cm})$ and it deminished $(2.03 \mathrm{mS} / \mathrm{cm})$ towards the end of the crop cycle (Figure 7). These data allowed us to characterise the evolution of the salinity of the plot during irrigation.

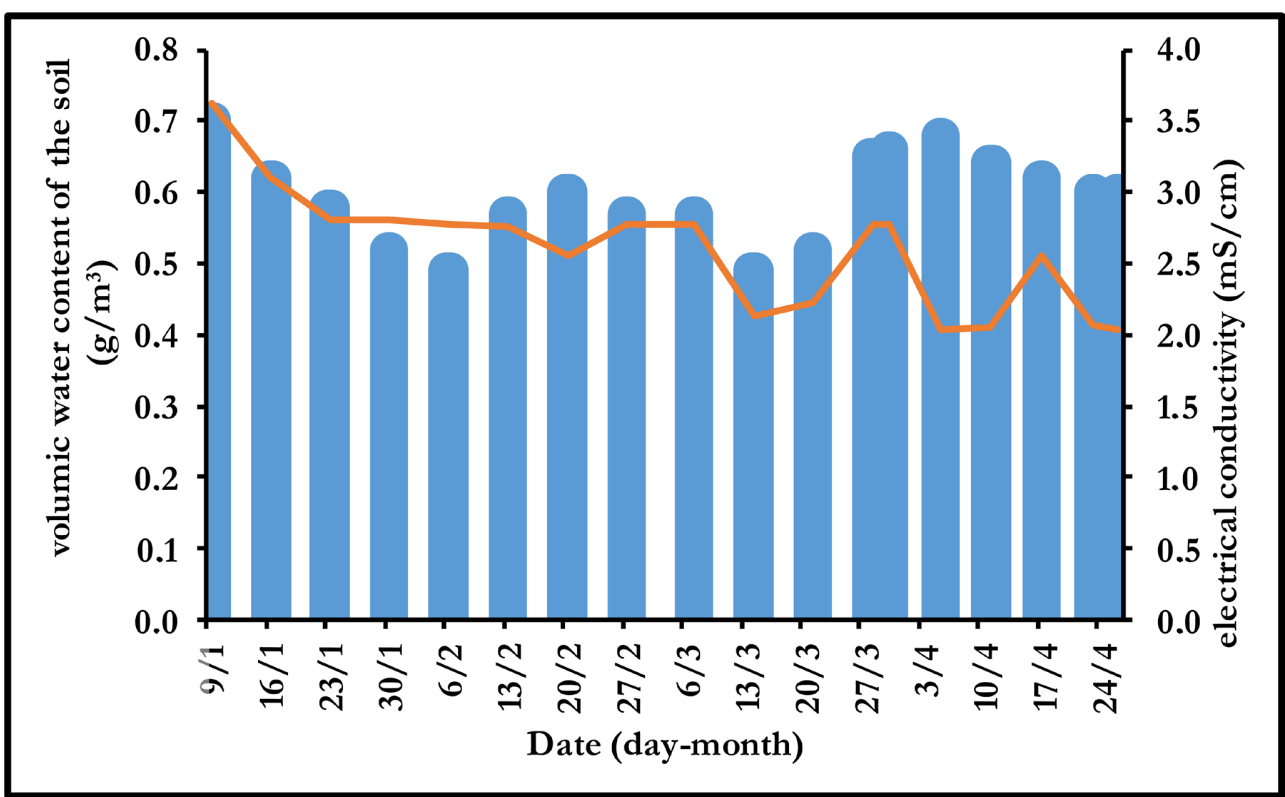

Figure 7. Comparative evolution of soil electrical conductivity as a function of soil volumic water content.

\subsection{Hydrosaline Dynamics}

A simulation was made using the electrical conductivity data in order to determine the monthly salt content during the campaign. As onion bulb development does not exceed $30 \mathrm{~cm}$ in depth (data sheet), a $30 \mathrm{~cm}$ profile was used to estimate these quantities. From the soil data and electrical conductivity data, a monthly salt deposit was established. In the absence of a significant rise in the groundwater table, salt inputs were low. They were in the order of 0.2 to $0.5 \mathrm{t} / \mathrm{ha}$ (Figure 8). These salt inputs were important from the beginning of the irrigations ( $0.5 \mathrm{t} / \mathrm{ha}$ in January), 
decreased between February and March $(0.22 \mathrm{t} / \mathrm{ha})$ and increased during the last month of irrigation $(0.3 \mathrm{t} / \mathrm{ha}$ ) (Figure 8). The ANOVA performed on the quantities of salt during the campaign reveals two groups of salt intakes: group a (January-February) and group $b$ (March-April). In each group the ANOVA showed that the difference was non-significant ( $\mathrm{p} 1=0.05$ and $\mathrm{p} 2=0.04)$ at the $95 \%$ confidence interval (Figure 8). The monthly averages of salt quantities that had the same letter were statistically identical. Therefore, the monthly averages of salt quantities between January and February as well as between March and April were statistically identical (Figure 8).

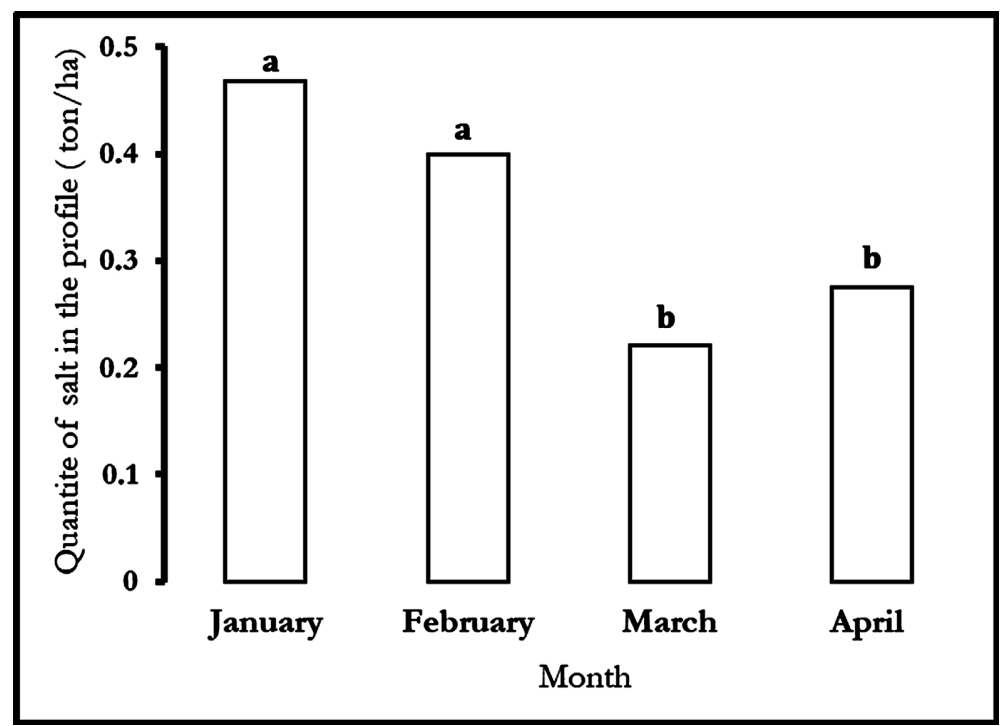

Figure 8. Quantite of salt in a $30 \mathrm{~cm}$ profile in irrigated onion cultivation.

\section{Discussion}

In the delta, the major problems of irrigated onion cultivation remained water supply and irrigation frequency. Work by [6] showed that many irrigated onion crops in West Africa present a rate of flowering from 30\% - 90\% the first month of cultivation. This situation leads to poor onion bulb production. So as to define conditions of irrigation allowing to reduce the rate of flowering from the first month, a water regime was applied to the local onion variety "Violet de Gelrni" in the dry season. On the basis of the results of this study, it would be interesting to define which was the water mass would be suitable for the crop for a good development of the plants during the crop cycle. After a pre-irrigation to prepare the plots for transplanting the young plants, the first irrigation took had intervened two weeks later in order to allow the development of the root system, which was still very superficial during transplanting. On all the plots used, our results had revealed a good development of the root system, the crops and a good development of the onion bulbs. Work on the description of onion cultivation techniques in the Sudano-Sahelian region had shown that the stingray irrigation system on ridges was more profitable in terms of yield and water management [5]. In addi- 
tion, in the recommendation of the cultivation technique, it was said that "waterlogged" onion roots were find themselves in unable to play their pumping role during the hot hours of the day, resulting in wilting of the foliage [5].

In our study, water losses by evapotranspiration were evaluated and a variation according to the development stages of the crop was observed. As evapotranspiration in crops is related to crop coefficients, it increases as soon as this constant is important. It was maximum in the bulb maturation phase (6.07 $\mathrm{mm}$ /day) with a crop coefficient of 1.05 . In the absence of a permanent water cover and total canopy cover the sum of water losses by evapotranspiration would be equal to the evapotranspiration of the crop to which should be added that of the soil. Van Laere (2003) in the "Mèmento de l'irrigation" showed that the evapotranspiration of a crop was related to the crop coefficients and varied according to the development stages of the crop. Work done in the same area of the delta by [18] with the same setup on another speculation (rice cultivation) had found that evapotranspiration varied according to the development stages of the crop.

The results of this study had show that the water masses (water masse volumic) present in the soil were more than sufficient to cover the crop water needs during the campaign. Furthermore, we had observed movement of the water table during the crop cycle, which could be explained by the fact that the soil water content exceeded the field capacity during the growth phase of the onion, resulting in water losses by percolation. Practical applications on the use of soil water mass after irrigation for optimal onion bulb production under the soil-climate conditions in the delta were proposed in this study. Despite the different water needs according to the development phases of the crop, a rational use of water would be necessary, all the more so as the needs were more important at the beginning of bulbing than during the vegetative stages [19]. The above meteorological, soil and crop data were used to optimise the irrigation calendar. After an initial irrigation to prepare the plots for transplanting, the initial water content was assumed to be equal to the field capacity. The knowledge of the field capacity of the plot made it possible to determine the minimum quantity of water to be supplied to the crop. During the bulb ripening period $\left(78^{\text {th }}\right.$ to $95^{\text {th }}$ days), growers had not hesitated to provide important quantities of water to the plots to keep the soil moist at all times (mass water volumic of $0.700 \mathrm{~g} / \mathrm{m}^{3}$ ) in order to buckle this phase and to wait a better yield. The results showed doses of irrigation understood between $50 \%$ and $60 \%$ of maximal water requirement during the phase of bulbification were sufficed to reduce the rate of undesirable floral induction and to allow to reach very good outputs in marketable bulbs. In irrigated onion cultivation during the bulb ripening phase, when one keeping the soil relatively moist we put on the brakes root development while promoting bulb enlargement [20].

Comparing the amount of water used for market gardening (irrigated onion cultivation) with that used for rice cultivation in the same area during the same 
period [18], it was found that irrigated onion cultivation uses a lower volume of water, resulting in low groundwater recharge, unlike rice cultivation. This could be explained by the type of irrigation (stingray irrigation between the ridges) and the frequency of irrigation, which did not allow the water to stagnate for more than 20 hours. During irrigated onion cultivation, only the main canal was filled; the quantities of water brought to the plot were clearly low and in no case allow a water slide to remain above the crop as observed in rice cultivation [18]. Indeed, the water requirements of onions (the main crop during market gardening) were estimated to be between 6 and $9 \mathrm{~mm} /$ per irrigation depending on the stage of development. These results corroborated those of [4].

Monitoring of the electrical conductivity of the plots during irrigation was carried out in order to map the salinity of the irrigated onion growing area. At the beginning of irrigation the electrical conductivity was $3.62 \mathrm{mS} / \mathrm{cm}$ on a 30 $\mathrm{cm}$ profile, it decreased towards the end of the irrigations to reach $2.06 \mathrm{mS} / \mathrm{cm}$. The electrical conductivity of the irrigation water was low and had not change during irrigation. Once water was supplied to the plots, the salt on the soil surface was dissolved. In addition, in the absence of a permanent water slide and the rise of the water table, the electrical conductivity recorded at the plots had remained low [21]. It had subsequently increased during the maturation phase of the bulbs corresponding at the moment of important soil water content. [22] showed in his work that the electrical conductivity also depended to a large extent on the soil water content. This electrical conductivity was low compared to that recorded in rice cultivation $(3.5 \mathrm{dS} / \mathrm{m})$ [21].

From the knowledge of the data linked at crop and pedology, a simulation of the quantities of salt trapped in the profile during the irrigations was carried out. The quantities of salt accumulated in the profile were significant during the first two months of irrigation (January recorded quantities of salt were $0.47 \mathrm{t} / \mathrm{ha}$ and in February $0.40 \mathrm{t} / \mathrm{ha}$ ). When irrigation had stopped at the end of the campaign, a hydrosaline flow was trapped in the sediments of the superficial layer. With high evapotranspiration in the delta area, once the water was lost, the salt had remained concentrated in the superficial layers of the soil. According to [23], when irrigation was stopped, salt was trapped in the sediments (pores) of the soil superficial layers. Once the irrigation water was applied, there was leaching from the superfical layer and at the same time percolation was observed resulting the hydrosaline flux out of the plot and/or towards the deep areas. This process would explain the decrease in salt quantities recorded in March (0.221 t/ha). In the last month of the campaign (April), with high evapotranspiration and spaced irrigation frequency leading to a drying of the soil surface, the salt started to concentrate in the superficial horizons, hence a slight increase in the amount of salt $(0.275$ ton/ha).

\section{Conclusions}

The study had allowed to see the different constraints related to the stingray ir- 
rigation system practiced in onion cultivation. As far as water inputs were concerned, the general observation was that they were significant compared to the estimated quantities of water that would allow for good plant development of the plant in order to obtain an optimal yield. From a quantitative point of view, the water balance essay had showed that the water inputs were greater than to the recoveries by evapotranspiration, allowing the crop to curl its cycle without water stress.

This study had showed that the transfer of water to the groundwater table during the irrigation period was negligible. In sum, the risks of degradation of the plots by the arrival of groundwater were low, or even non-existent, compared to the submersion irrigation system practiced in rice cultivation in the Senegal River Delta.

\section{Conflicts of Interest}

The authors declare no conflicts of interest regarding the publication of this paper.

\section{References}

[1] Camara, M. (1997) Contribution à l'étude des stratégies de lutte intégrée contre la maladie des racines roses de l'oignon (Allium cepa L) causée par Pyrenochaeta terrestris (Hansen) Gorentz, Walker et Larson. Thèse de doctorat de troisième cycle, Université Cheikh Anta Diop de Dakar, Dakar, 118 p.

[2] Wade, I., David-Benz, H. and Egg, J. (2004) Information et régulation des filières maraîchères au Sénégal. Cahiers Agricultures, 13, 148-157.

[3] Pagès, J. (1993) Les systèmes de cultures maraîchers dans la vallée du fleuve Sénégal, pratiques paysannes, évolution. In: Atelier ISRA. ORSTOM sur la Culture Irriguée dans la Moyenne Vallée du Sénégal, CIRAD-CA, Saint-Louis, 171-187.

[4] Gning, A.A. (2015) Etude et Modélisation Hydrogéologique des Interactions Eaux de Surface-Eaux Souterraines dans un Contexte d'Agriculture Irriguée dans le Delta du Fleuve Sénégal. Thèse de Doctorat en Sciences de l'ingénieur Université de Liège et de Docteur ès Sciences Université Cheikh Anta Diop de Dakar, Dakar, 259 p.

[5] M’ Biandoun, M. and Essang, T. (2008) Importance économique de l'oignon cultivé sur billons sur terrain plat avec irrigation à la raie. Sommairel Inhoud/Sumario, 26, 70-73.

[6] Sanon, M., Rouamba, A. and Nicolas, H. (2001) Influence de l'irrigation sur le taux de montaison de l'oignon (Allium cepa L.) en première année de culture. Bulletin de la Recherche Agronomique du Bénin, 34, 9-20.

[7] Gay, J.P. and Dancette, C. (1995) La diversification des cultures. In: Nianga, laboratoire de P agriculture irriguée en moyenne vallée du Sénégal, ORSTOM-ISRA, Paris, 281-300.

[8] Diene, R.S. (1998) Riziculture et dégradation des sols en vallée du fleuve Sénégal: analyse comparée des fonctionnements hydro-salins des sols du delta et de la moyenne vallée en simple et double riziculture. Thèse de Doctorat-Ingénieur en Géologie appliquée, Université Cheikh Anta Diop de Dakar, Dakar, 176 p.

[9] SAED (2008) Projet de Réhabilitation et d'Extension des casiers de la Rive Gauche 
du Marigot Lampsar (Lampsar,Ndelle, Ndiaye et Ngomène). Etude pédologique supplémentaire. République du Sénégal, ministère de l'Agriculture. SAED, Dakar, $172 \mathrm{p}$.

[10] Le Brusq, J.Y. (1984) Quelques observations sur la dynamique des sels et des etats de surface dans des sols du delta du fleuve Sénégal. Centre de Dakar-Hann, ORSTOM, $17 \mathrm{p}$.

[11] Fall, S. (2006) La problématique de la gestion de l'eau à l'échelle des périmètres irrigués du Delta du fleuve Sénégal: Le bilan d'utilisation de l'eau et les coûts de l'irrigation dans les périmètres irrigués autour de l'axe hydraulique du Lampsar. Mémoire de DEA Université Gaston Berger de Saint Louis, Saint-Louis, 97 p.

[12] SAED (2012) Bulletin d'information sur la culture irriguée: République du Sénégal, ministère de l'Agriculture. SAED, Dakar, $22 \mathrm{p}$.

[13] Allen, R.G., Pereira, L.S., Raes, D. and Smith, M. (2004) Crop Evapotranspiration (Guidelines for Computing Crop Water Requirements): FAO Irrigation and Drainage Paper No. 56. Food and Agriculture Organization, Rome.

[14] Van Laere, P.E. (2003) Mémento de l'irrigation, Collection «Manuels Techniques». Ingénieur Assistance Internationale-Ingénieurs sans Frontiers, Bruxelles, 15 p.

[15] Gaidi, L. and Ichola, I.A. (2003) Utilisation des sondes TDR pour estimer la masse de soluté retenu par une couche d'argile lors d'une infiltration. Bulletin of Engineering Geology and the Environment, 62, 47-56. https://doi.org/10.1007/s10064-002-0167-0

[16] Musy, A. and Soutter, M. (1991) Physique du sol. Collection Gérer l'environnement. Presses Polytechniques et Universitaires Romandes, Rome, 335 p.

[17] Aubert, G. (1978) Méthodes d'analyse des sols. 2ème Edition, Centre National de Documentation Pédagogique, Marseille, 198 p.

[18] Kaly, E., Malou, R. and Akpo, L.E. (2016) Évaluation du modèle AquaCrop de la FAO en riziculture irriguée dans le Delta du Fleuve Sénégal. Journal of Animal \& Plant Sciences, 30, 4781-4796.

[19] Leroy, M. (1994) Cause de variation du rendement de l'oignon à la réunion. Mémoire d'ingénieur. INAPG, Paris, $57 \mathrm{p}$.

[20] Doorenbos, J. (1980) Réponse des rendements à l'eau. FAO, Rome, 235 p.

[21] Kaly, E., Malou, R., Sarr, O., Ngom, D., Diatta, S. and Guisse, A. (2020) Management of the Water Slide Brought and Saline Flow in Irrigated Rice Cultivation in the Senegal River Delta. International Journal of Development Research, 10, 41803-41809.

[22] Schneider, S. (2009) Estimation des paramètres hydrodynamiques des sols à partir d'une inversion jointe de données d'infiltration et de résistivité électrique. Thèse de doctorat, Université Paris-Sud, Orsay, 143 p.

[23] Ndiaye, B., Molénat, J., Ndoye, S., Boivin, P., Cheverry, C. and Gascuel-Odoux, C. (2008) Modélisation du transfert de l'eau et des sels dans les casiers rizicoles du Delta du Fleuve Sénégal. Journal of Water Science, 21, 325-336.

https://doi.org/10.7202/018778ar 